\title{
The Impact of Peer Feedback on EFL Learners' Writing Performance and Writing Anxiety
}

\section{Amin Bolourchi ${ }^{1} \&$ Maryam Soleimani ${ }^{2 *}$}

\section{* Correspondence: \\ m.soleimani.1361@gmail.com \\ 1. Ministry of Education, Urmia, West \\ Azarbaijan, Iran \\ 2. Department of Humanities, \\ Farhangiyan University, Urmia, West \\ Azarbaijan, Iran}

Received: 17 July 2020

Revision: 18 September 2020

Accepted: 6 November 2020

Published online: 20 March 2021

\begin{abstract}
The present study aimed at investigating the effect of peer feedback (PF) on EFL learners' writing performance and writing anxiety. To this end, two intact classes including 48 intermediate EFL learners were selected and assigned into two groups of experimental and control (24 learners in each). This study had a quasi-experimental design including pre-test, treatment, and post-test to assess the students' overall writing performance before and after the PF sessions. For data collection, the researchers used pre-test, post-test, 7 writing topics, and Cheng's (2004) Second Language Writing Anxiety Inventory (SLWAI). The results of paired sample t-test and Mann-Whitney $\mathrm{U}$ Test revealed that the experimental group outperformed the control group due to the implementation of PF. Moreover, the researchers conducted Cheng's SLWAI questionnaire at the end of the study. The findings indicated that the anxiety level of the experimental group receiving PF decreased to a significant extent. The implications are discussed in terms of writing instructors' use of PF into writing classes to make the environment safer and more comfortable for the language learners to flourish their ideas.
\end{abstract}

Keywords: feedback, peer feedback, writing anxiety, writing performance, $\underline{\text { EFL learners }}$ 


\section{Introduction}

In the context of learning English as a second language (ESL) or as a foreign language (EFL), learners write to their teachers or peers, their target audience, with the purpose of developing their writing skills in English. Writing can be defined from various perspectives. In process approach, writing is defined as "a multiple-draft process which consists of generating ideas, writing a first draft with an emphasis on content; second and third drafts to revise ideas, and the communication of those ideas" (Keh, 1990, p. 294). In this definition, students' learning to write proceeds through multiple processes that involve planning, drafting, revising, and editing (Hyland, 2003; Keh, 1990). From a different perspective, writing is approached as a social process (Faigley, 1986). In this perspective, writing is defined as an interactive and a social activity, where the writer communicates with his/her target audience (Widdowson, 1984). As an interactive and social process, writing activities should provide an opportunity for the learners to communicate with their audience (Cinar, 2014; Soleimani \& Modirkhamene, 2020). Therefore, learners should develop awareness on their writing and have an idea of the strengths and weaknesses of their writing (Tsui \& $\mathrm{Ng}, 2000$ ).

While acquiring productive skills such as speaking and writing, learners may need regular and sufficient practice by producing speeches or texts in English language. In the case of writing, learners write multiple drafts and revise them constantly to develop their writing skills. Thus, the process of developing writing skill requires lots of practice and adequate feedback from multiple sources, either by teachers or peers, or both (Keh, 1990). Feedback is essential for writing process to be successful (Chaudron, 1984). EFL or ESL learners usually seek feedback provided by teachers to develop their writing in English. Writing instructors can provide both surface level feedback, aimed to focus on editing vocabulary, grammar, and punctuation errors, and global level feedback on the development of ideas, audience, purpose, and organization features (Hendrickson, 1978). Taking this into account, the feedback process may require more patience, effort, and time for writing process to lead development in learners' writings (Rollinson, 2005).

For this reason, peer feedback (PF) can be used as a second source of feedback for learners. By this way, learners can get feedback on their writing from different sources, which is their peer. PF that learners get while developing their writing skills has been proven to have numerous benefits (Hansen \& Liu, 2005; Mendonca \& Johnson, 1994). One of the benefits of PF is that it could reduce writing anxiety levels of the learners (Jahin, 2012; Kurt \& Atay, 2007). Based on the previous studies conducted on the effect of PF on learners' writing anxiety, it can be said that learners might generate more motivation and positive attitudes towards writing thanks to PF application (Min, 2005) because PF builds a sense of audience and provides the opportunity of writing to a real audience (Tsui \& Ng, 2000). Regarding these issues, this study aimed at investigating the impact of PF on EFL learners' overall writing performance and writing anxiety.

\subsection{Statement of the Problem}

Although the previous studies enriched the understanding of the impact of PF on learners' writing performance, there is still a need for research exploring whether PF can be used to improve writing performance and to reduce writing anxiety levels of language learners in the EFL context of Iran. The major novelty of this study lies in its attempt which has been carried out to identify, analyze, and observe the impacts that PF may have on students' written production as well as its effect on anxiety level. To the best of the researchers' knowledge, clarifying these issues is an underinvestigated research area in the realm of feedback in general, and PF in particular. Considering the important role of $\mathrm{PF}$ in EFL classrooms and regarding the few numbers of comparative studies containing PF, anxiety, and writing performance, it is hoped that through this study contributions are made to a better understanding of PF and its effectiveness in teaching and learning in an EFL context. Thus, this study attempted to explore the impact of PF on EFL learners' writing performance and writing anxiety. To this end, the researchers formulated the following research questions.

\subsection{Research Questions}

The questions of this study are as follows:

1) Does PF have any significant effect on EFL learners' writing performance?

2) Does PF have any significant effect on EFL learners' writing anxiety level?

\subsection{Research Hypotheses}

Based on the above research questions, the hypotheses of the study are as follows: 
1) PF has no significant effect on EFL learners' writing performance.

2) PF has no significant effect on EFL learners' writing anxiety level.

\section{Literature Review}

Writing is not a newly taught skill. It is learned and taught because it is a social necessity and a way of communicating and learning (Lindemann, 1982). However, writing did not get attention until the 1960s, as it was a priority neither for teachers nor for students (Richards \& Rodgers, 1986). Writing can be simply defined as words on paper that students write based on what they have learned. Onozawa (2010) also states that writing has several stages; namely, pre-writing, drafting, and revising. Moreover, this process may also include thinking, planning, and evaluating as well. Rahimi (2009) states that changing the approach from product to process writing necessitates underlining multiple drafting of students' writing and requires teachers' giving feedback to multiple pages. It can be notified that with this shift, the importance of feedback increased significantly and become one of the most important components in writing. Huang $(2004,2012)$ states that the students are expected to cooperate, collaborate, and assist each other through discussion. It can be said that feedback might be given by the teachers or peers as well. If the feedback is given by peers, students may have chance to have a collaborative environment in this process.

Keh (1990) states that feedback is a basic element in process approach. She explains feedback in the field of writing as an input that provides information from a reader to a writer for revision. To explain the importance of giving feedback in language teaching, Richards and Lockhart (1994) state that "providing feedback to learners on their performance is an important aspect of teaching. Feedback may serve not only to let learners know how well they have performed but also to increase motivation and build a supportive classroom climate" (p. 188). With the approach of writing process, PF has become a more increasingly vital component in a writing class owing to advocating studentcentered learning (Lei, 2017). PF has an important role in process writing. The literature has also highlighted that the use of PF is increasingly seen as an assistive and attractive method in teaching writing (Nicol, 2010). Bartels (2003) pointed out that PF creates an atmosphere in which learners have the opportunity for communicative writing. Liu and Hansen (2002) and Koka and Hein (2006) stated that in PF interactions, students have the roles and responsibilities that are normally performed by teachers to comment on or criticize their peers' drafts in oral and written forms.

Although PF is strongly supported by the literature, like any technique, it is faced with some criticism. For example, Leki (1990) stated that students have a tendency to give advice that does not help revision, and the student may not find their peers' comments valid. Similarly, Nelson and Murphy (1993) pointed out that the students may not trust their peers' comments as they are not native speakers. Since ESL students are not native speakers, they need to be taught, guided, and controlled to make PF sessions more effective (Celce-Murcia, 1991). If they aren't trained, the students may pay more attention to surface matters rather than content and organization of ideas, and they may act authoritatively rather than work in collaboration (Mangelsdorf \& Schlumberger, 1992).

Research studies also revealed that ESL writing anxiety might have profound effects on ESL writing performance (Hussein, 2013; Liu \& Ni, 2015; Xiu Yan \& Wang, 2012). Anxiety is a factor that impacts the writing performance of EFL/ESL learners, especially with low English writing proficiency (Abdel Latif, 2012; Susoy \& Tanyer, 2013). In other words, writing anxiety negatively affects ESL/EFL learners' writing quality. Second language writing anxiety can be defined as "a general avoidance of writing and of situations perceived by the individuals to potentially require some amount of writing accompanied by the potential for evaluation of that writing" (Hassan, 2001, p. 4). In literature, this phenomenon has been scrutinized under various concepts such as "apprehension, block, or fear but anxiety and apprehension are likely to be the most interchangeable used terms to describe that writing psychological construct" (Hussein, 2013, p.36).

In several studies, researchers have demonstrated a correlation with writing anxiety and writing performance (DeDeyn, 2011; Erkan \& Saban, 2011; Malec, 2011). Research on the relationship between anxiety and PF has shown that training learners on how to give and receive PF is of vital importance to enhance the positive impacts of PF on reducing writing anxiety (Kurt \& Atay, 2007; Susoy \& Tanyer 2013). There are recent studies revealing the strengths of PF in developing EFL/ESL writing skills (Austria, 2017; Brusa \& Harutyunyan, 2019; Khalil, 2018; Min, 2016). Kuyyogsuy (2019) investigated the influence of PF on students' writing ability. The findings showed that the students' writings had improved significantly. Moreover, students stated that PF was a valuable and exciting experience for them and helped them get familiar with the writing process and developed their critical thinking skills, collaboration, and autonomy. In the same vein, Yastibas and Yastibas (2015) conducted a study on the effectiveness of PF on reducing 
anxiety level of the language learners while writing. They investigated 16 students in eight weeks. The results indicated that the language learners experienced less anxiety and they were more confident after getting some feedback from their peers rather than their teachers.

Moreover, Cinar's (2014) study supported the view that PF training and practice can reduce anxiety levels of EFL learners by creating a more informal and collaborative learning atmosphere. Another result of the study based on the interviews was that PF practices created a more supportive, collaborative, interactive, educational, and less threatening learning environment. In addition, Farrah (2012) studied the impact of peer reviewing on students' attitudes towards $\mathrm{PF}$ and their writing performances. The study concluded that the writing performances of the participants who received PF increased and they developed positive attitudes towards PF. Besides, the study revealed that there was an increase in students' motivation to write due to peer-reviewing practices. Furthermore, Kurt and Atay (2007) conducted a research on whether PF practices had any impacts on foreign language writing anxiety. The findings indicated that the participants who had training on PF and gave PF for a period of time experienced decrease in their anxiety levels. The interviews revealed that the majority of the participants found PF helpful and enjoyed the PF discussions.

\section{Methodology}

\subsection{Design of the Study}

This study had a quasi-experimental design including pre-test, treatment, and post-test to assess the students' overall writing performance before and after the PF sessions. The variables of the study were peer feedback as an independent variable and writing performance and writing anxiety as dependent variables. Additionally, it included a questionnaire to be filled out before and after the treatment sessions to check out the language learners' anxiety level. These tests and questionnaire provide numerical results of the students' performance and anxiety level.

\subsection{Participants}

The participants of the current study were chosen through Iran Language Institute (ILI) Placement Test. Two intact classes including 48 female EFL learners learning English at intermediate level at the ILI in Urmia, Iran were selected. One of the classes was selected as the experimental and the other one as the control group ( 24 in each group). The ages of the participants ranged from 15 to 20 and the participants were talking Turkish, Farsi, and Kurdish as their native languages.

\subsection{Instruments}

In the current study, the following instruments were employed in data collection process.

\subsubsection{English Language Institute Placement Test}

The reliable ILI Placement test is used at the beginning of each term and includes items on grammar (60) and vocabulary (60) followed by an interview. It is used to homogenise the participants' proficiency level in the beginning of the study.

\subsubsection{Pre-test and Post-test}

Language learners' writings in pre-test and post-test were assessed in terms of content, organization, and language through IELTS scoring module. The scale is a score between one and nine. Within the treatment, the raters also rated the writings produced by both experimental and control groups to make the students aware of their performance (it should be mentioned that these scores were not the focus of the present study). Inter-rater reliability among these raters was found out through the Pearson correlation coefficient considering overall writing performance.

\subsubsection{Cheng's (2004) Second Language Writing Anxiety Inventory}

In order to measure participants' writing anxiety, the researchers used Cheng's (2004) Second Language Writing Anxiety Inventory which includes 22 items on a Five-point Likert scale ranging from " 1 " (strongly disagree) to " 5 " (strongly agree). A higher score indicates a higher level of ESL writing anxiety. The researchers piloted the questionnaire to calculate its reliability which was high (0.91).

\subsection{Procedure}

In the beginning of the study, two intact intermediate classes were selected through the ILI Placement Test and assigned into experimental and control groups including 24 students in each class. Before the treatment, all the 
participants in both groups filled out the writing anxiety questionnaire, which had been piloted to ensure its reliability, in the first session. However, the researchers informed the experimental group about PF, the types of PF, and how they could give PF before the main study. The researchers then checked the understanding of the participants about $\mathrm{PF}$ practice to be sure that all the participants clearly understood what PF was, how important it was, and how it could be implemented in an effective way.

To this end, two sample writing papers were given to the participants in the experimental group. They were required to write feedback to these sample papers individually in English. A 45-minute class-hour for each paper was given to the students as the time-limit. The sections of the sample writing papers consisted of writing task instructions, task requirements, the checklists for the feedback writers, and boxes to write comments in English. The checklists were parallel to the task requirements. In the second class hour, the researchers checked the papers and communicated with participants one by one to point out errors in corrections and missing parts in their feedback. This procedure continued for two sessions.

Then, the participants were asked to complete a writing task in the first class hour. In the second part of the class hour, they were asked to give feedback to their classmates' papers, read, and complete the checklist on the paper which was related to the task, and write comments and feedback in the comment box in English. Next session, the writer of the original paper, the PF provider, and the researchers came together and the peer explained his feedback orally. The researchers listened to each pair carefully and showed the errors if there were any. The reason why the researchers themselves checked the papers and listened to all the students was to see if participants could provide PF effectively and make sure that participants could focus on both global and local level errors. During that practice, both English and Persian were used for communication between students, and between the researchers and students. The participants were allowed to use Persian throughout the process so that they could feel relax and work in a positive and collaborative atmosphere where interaction was constituted.

During the treatment sessions, in the beginning of each class hour, the participants completed a writing task. In the second section of the class hour, they gave feedback to their peers' papers and communicated the written feedback. The researchers just walked around and listened to their feedback communication without any comments or interference. The participants in the experimental group completed seven tasks, gave, and received PF. While the researchers helped, commented, and provided feedback to the experimental group on how to provide feedback during $\mathrm{PF}$ trainings, they did not interfere or help them during PF practices.

During the study, the participants in both control and experimental groups completed the same seven tasks. The difference between these two groups was that while the control group received only teacher feedback, the experimental group gave and received PF. Another difference between the two groups was that the experimental group wrote one more task than the control group, which was in the training sessions. All the tasks used in the training sessions for the experimental group and practice sessions for both control and experimental groups were the same. In the last session, anxiety questionnaire was administered again to both groups to see if foreign language writing anxiety levels of the participants changed and if PF had an impact on the foreign language writing anxiety. Finally, all the participants took part in a post-test to be checked out their writing after treatment.

\subsection{Data Analysis}

For the analysis of the quantitative data of the present study, and in order to report the inferential statistics, the researchers analyzed the results of the writing anxiety questionnaire given in the first and last session to the participants using paired sample t-test to see what had changed in terms of anxiety levels. In order to measure the changes in the writing anxiety levels of the participants, standard deviation and mean scores were calculated both for pre- and postquestionnaire, and for the inferential statistics, Paired samples t-test was utilized. On the other hand, to compare the pre- and post-application results of the control and experimental groups, and to check the language learners' progress in writing, an independent sample t-test and Mann-Whitney U Test were used. Moreover, the researchers used Pearson correlation coefficients to ensure the inter-rater reliability of the scores.

\section{Results}

4.1 Quantitative Analysis for Inter-rater Reliability of the Scores 
In all phases of scoring in the current study, the researchers tried to ensure the inter-rater reliability of the scores. To this end, Pearson correlation coefficients were run. The correlation coefficient in pre-test and post-test are illustrated in the following Tables.

Table 1. The inter-rater reliability for control group pre-test scores

\begin{tabular}{lcc}
\hline Pre Control Rater2 & & \\
\hline Pre Control Rater1 & Pearson Correlation & .860 \\
& Sig. (2-tailed) & .000 \\
& $\mathrm{~N}$ & 24 \\
\hline
\end{tabular}

As it is evident from Table 1, the result of Pearson Correlation Coefficient is significant; therefore, it can be concluded that the correlation $(0.86)$ between the two raters was significant.

Table 2. The inter-rater reliability for experimental group pre-test scores

\begin{tabular}{|c|c|c|}
\hline Pre Experimental Rater2 & & \\
\hline Pre Experimental Rater1 & Pearson Correlation & $.891^{* *}$ \\
\hline & Sig. (2-tailed) & .000 \\
\hline & $\mathrm{N}$ & 24 \\
\hline
\end{tabular}

Table 2 shows that the result of Pearson Correlation Coefficient is significant $(0.89)$ between the two raters.

Table 3. The Inter-rater reliability for control group post-test scores

\begin{tabular}{lcc}
\hline Post Control Rater2 & & \\
\hline Post Control Rater1 & Pearson Correlation & .839 \\
& Sig. (2-tailed) & .000 \\
& $\mathrm{~N}$ & 26 \\
\hline
\end{tabular}

As for the pre-test raters, Table 3 indicates that the correlation between the two raters for the control group post-test scores $(0.83)$ is significant.

Table 4. The Inter-rater reliability for experimental group post-test scores

\begin{tabular}{llc}
\hline Post Experimental Rater2 & & \\
\hline Post Experimental Rater1 & Pearson Correlation & .909 \\
\cline { 2 - 3 } & Sig. (2-tailed) & .000 \\
\cline { 2 - 3 } & $\mathrm{N}$ & 24 \\
\hline
\end{tabular}


Table 4 showing the correlation coefficient for the experimental group post-test scores manifested that the two raters were in a complete agreement regarding scoring.

\subsection{Quantitative Analysis for Pre-test}

To begin with, the researchers checked the normality of data distribution for the test scores by running KolmogorovSmirnov test. Table 5 below indicates the descriptive statistics for the pre-test scores, and Table 6 illustrates the test of normality results.

Table 5. Descriptive statistics for the scores on pre-test

\begin{tabular}{|c|c|c|c|c|c|}
\hline & Groups & & & Statistic & Std. Error \\
\hline \multirow{12}{*}{$\begin{array}{l}\text { Pre } \\
\text { test }\end{array}$} & \multirow[t]{6}{*}{ Control } & Mean & & 5.05 & .07816 \\
\hline & & \multirow{2}{*}{$\begin{array}{l}\text { 95\% Confidence Interval } \\
\text { for Mean }\end{array}$} & Lower Bound & 4.89 & \\
\hline & & & Upper Bound & 5.21 & \\
\hline & & Std. Deviation & & .38 & \\
\hline & & Minimum & & 4.25 & \\
\hline & & Maximum & & 5.75 & \\
\hline & \multirow[t]{6}{*}{ Experimental } & Mean & & 5.19 & .10092 \\
\hline & & \multirow{2}{*}{$\begin{array}{l}\text { 95\% Confidence Interval } \\
\text { for Mean }\end{array}$} & Lower Bound & 4.98 & \\
\hline & & & Upper Bound & 5.40 & \\
\hline & & Std. Deviation & & .49 & \\
\hline & & Minimum & & 4.25 & \\
\hline & & Maximum & & 6.50 & \\
\hline
\end{tabular}

Table 5 shows that the mean scores of the control and experimental groups for the pre-test scores are 5.05 and 5.19, respectively. At the same time, the standard deviations of both groups are 0.38 and 0.49 , respectively.

Table 6. One-sample Kolmogorov-Smirnov test for the pre-test scores

\begin{tabular}{lccc}
\hline & & Control Pre & Experimental Pre \\
\hline $\mathrm{N}$ & & 24 & 24 \\
\hline Normal Parameters & Mean & 5.0521 & 5.1979 \\
& Std. Deviation & .38292 & .49442 \\
\hline Most Extreme Differences & Absolute & .196 & .291 \\
& Positive & .137 & .291 \\
& Negative & -.196 & -.136 \\
\hline Test Statistic & & .196 & .291 \\
\hline Asymp. Sig. (2-tailed) & & $.018^{\mathrm{c}}$ & $.000^{\mathrm{c}}$ \\
\hline
\end{tabular}


As is seen in Table 6, the data are found to violate the conditions for normal distribution and hence non-parametric equivalent of t-test, that is, Mann-Whitney U Test was employed for further analysis of the mean scores; the results of which have been presented in Table 7.

Table 7. Mann-Whitney U test for the pre-test scores

\begin{tabular}{lc}
\hline Mann-Whitney U & 244.000 \\
\hline Wilcoxon W & 544.000 \\
\hline Z & -.935 \\
\hline Asymp. Sig. (2-tailed) & .350 \\
\hline
\end{tabular}

The results of Table 7 show that the significance level for the pre-test scores is more than 0.05 ; therefore, it can be concluded that the difference between the two groups in the pre-test was not significant.

\subsection{Quantitative Analysis for Post-test}

After analyzing the scores of both experimental and control groups for the pre-test, the following sections took into account the analyses for the post-test scores, which begin with the descriptive statistics, proceed to the test of normality, and end with the results of independent samples t-test.

Table 8. Descriptive statistics for the post-test scores

\begin{tabular}{|c|c|c|c|c|c|}
\hline & Groups & & & Statistic & Std. Error \\
\hline \multirow[t]{12}{*}{ Post-test } & \multirow[t]{6}{*}{ Control } & \multicolumn{2}{|l|}{ Mean } & 6.17 & .11005 \\
\hline & & \multirow{2}{*}{$\begin{array}{l}95 \% \text { Confidence } \\
\text { Interval for Mean }\end{array}$} & Lower Bound & 5.94 & \\
\hline & & & Upper Bound & 6.40 & \\
\hline & & Std. Deviation & & .53 & \\
\hline & & Minimum & & 5.25 & \\
\hline & & Maximum & & 7.25 & \\
\hline & \multirow[t]{6}{*}{ Experimental } & Mean & & 7.78 & .10567 \\
\hline & & \multirow{2}{*}{$\begin{array}{l}95 \% \text { Confidence } \\
\text { Interval for Mean }\end{array}$} & Lower Bound & 7.56 & \\
\hline & & & Upper Bound & 7.99 & \\
\hline & & Std. Deviation & & .51 & \\
\hline & & Minimum & & 6.75 & \\
\hline & & Maximum & & 9.00 & \\
\hline
\end{tabular}

As it is shown in Table 8, the mean scores of the control and experimental groups for the post-test scores are 6.17 and 7.78 , respectively. At the same time, the standard deviations of both groups are 0.53 and 0.51 , respectively. It can be concluded from the results of the post-test scores that the experimental group members had higher scores compared with the control group members. 
Table 9. One-sample Kolmogorov-Smirnov test for the post-test scores

\begin{tabular}{lllc}
\hline Control Post & & & Experimental Post \\
\hline $\mathrm{N}$ & & 24 & 24 \\
\hline Normal Parameters & Mean & 6.17 & .78 \\
& Std. Deviation & .539 & .170 \\
\hline Most Extreme Differences & Absolute & .170 & .170 \\
& Positive & .170 & -.143 \\
\hline Test Statistic & Negative & -.142 & .170 \\
\hline Asymp. Sig. (2-tailed) & & .170 & .072
\end{tabular}

As Table 9 shows, the data are found to be normally distributed and hence parametric data analysis procedures must be taken into consideration. In this study, based on the research questions, independent samples t-test was employed for further analysis of the mean scores; the results of which have been presented in the Table 10.

Table 10. Independent samples T-test for the post-test

Levene's Test

for Equality of Variances

t-test for Equality of

Means

$95 \%$ Confidence Interval of the

Difference

F Sig. $\mathrm{t}$ Df Sig. Mean Std. Lower Upper

(2- Differe Error

tailed) nce Differenc

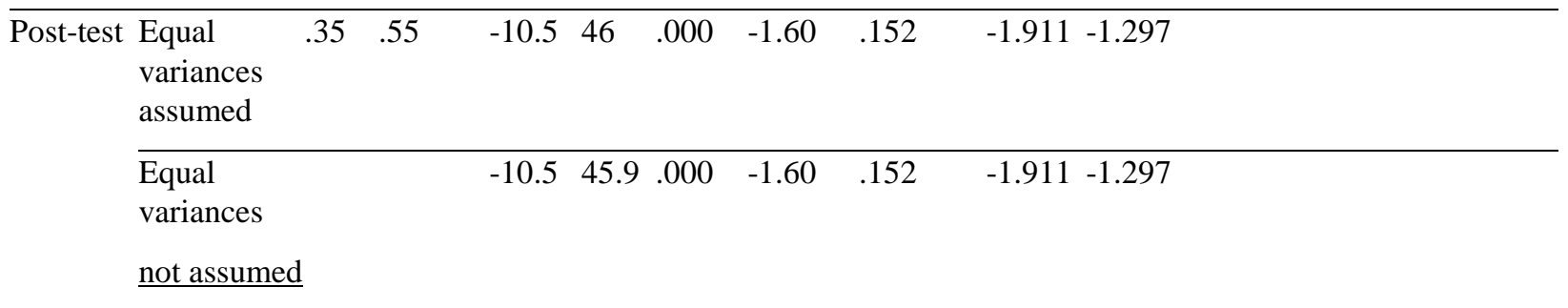

As it is clear from Table 10, the obtained results from the independent samples t-test manifest that the significance level is 0.00 , and hence, it can be concluded with 95 percent confidence level that the difference between the experimental group and the control group was significant, and the experimental group members outperformed the control group members. Therefore, the hypothesis stating that PF has no significant effect on EFL learners' writing performance was rejected. 


\subsection{Quantitative Analysis for the Questionnaire in Experimental Group}

This section deals with the analysis procedures relevant to the second research question dealing with the experimental group members' anxiety level before and after the treatment. As for the previous sections, the present section took into account the descriptive statistics, and after that the normality of the obtained data was obtained, and finally, the paired- samples t-test was run.

Table 11. Descriptive statistics of the SLWAI

\begin{tabular}{|c|c|c|c|c|}
\hline & & & Statistic & Std. Error \\
\hline \multirow[t]{6}{*}{ Pre Questionnaire } & Mean & & 63.00 & 4.95 \\
\hline & \multirow{2}{*}{$\begin{array}{l}\text { 95\% Confidence } \\
\text { Interval for Mean }\end{array}$} & Lower Bound & 52.74 & \\
\hline & & Upper Bound & 73.25 & \\
\hline & Std. Deviation & & 24.29 & \\
\hline & Minimum & & 25.00 & \\
\hline & Maximum & & 100.00 & \\
\hline \multirow[t]{6}{*}{ Post Questionnaire } & Mean & & 51.66 & 3.82 \\
\hline & \multirow{2}{*}{$\begin{array}{l}\text { 95\% Confidence } \\
\text { Interval for Mean }\end{array}$} & Lower Bound & 43.76 & \\
\hline & & Upper Bound & 59.57 & \\
\hline & Std. Deviation & & 18.72 & \\
\hline & Minimum & & 22.00 & \\
\hline & Maximum & & 89.00 & \\
\hline
\end{tabular}

Table 11 shows that the mean scores obtained from the questionnaires for the pre-test and the post-test are 63.00 and 51.66, respectively. At the same time, the standard deviations of the scores are 24.29 and 18.79 for the both data sets. These results show that the experimental group before the treatment suffered from more writing anxiety level and implementing PF relieved their anxiety to some extent. However, inferential statistics must be run to ensure the significance level of the above mentioned result (see Table 12).

Table 12. Paired samples T-test for the SLWAI

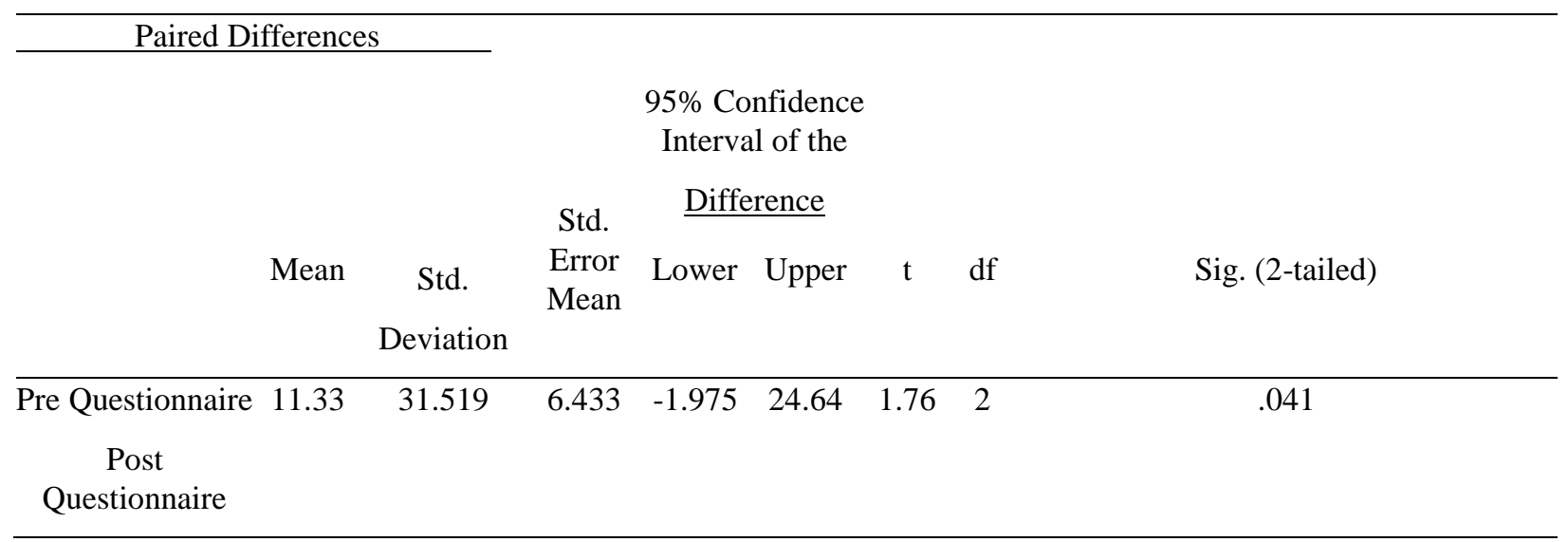


The results manifested in Table 13 revealed that the difference between the data collected before and after the treatment was significant and it can be concluded with 95 percent confidence level that through PF procedures, the language learners' writing anxiety decreased to a significant extent. Thus, the hypothesis stating that PF has no significant effect on EFL learners' writing anxiety level was rejected.

\subsection{Quantitative Analysis for the Questionnaire in Control Group}

The results of the questionnaire in pre and post-tests in control group are presented below.

Table 13. Descriptive statistics of the SLWAI

\begin{tabular}{|c|c|c|c|c|}
\hline & & & Statistic & Std. Error \\
\hline \multirow[t]{6}{*}{ Pre Questionnaire } & Mean & & 62.30 & 4.75 \\
\hline & \multirow{2}{*}{$\begin{array}{l}95 \% \text { Confidence } \\
\text { Interval for Mean }\end{array}$} & Lower Bound & 51.44 & \\
\hline & & Upper Bound & 59.40 & \\
\hline & Std. Deviation & & 22.48 & \\
\hline & Minimum & & 23.00 & \\
\hline & Maximum & & 100.00 & \\
\hline \multirow[t]{6}{*}{ Post Questionnaire } & Mean & & 60.56 & 4.82 \\
\hline & \multirow{2}{*}{$\begin{array}{l}95 \% \text { Confidence } \\
\text { Interval for Mean }\end{array}$} & Lower Bound & 51.14 & \\
\hline & & Upper Bound & 60.35 & \\
\hline & Std. Deviation & & 23.56 & \\
\hline & Minimum & & 22.00 & \\
\hline & Maximum & & 98.58 & \\
\hline
\end{tabular}

Table 13 shows that the mean scores obtained from the questionnaires for the pre-test and the post-test are 62.30 and 60.56, respectively. At the same time, the standard deviations of the scores are 22.48 and 23.56 for the both data sets. These results show that the control group's writing anxiety level was the same before and after the treatment. However, inferential statistics must be run to confirm the above mentioned result (see Table 14).

Table 14. Paired samples T-test for the SLWAI

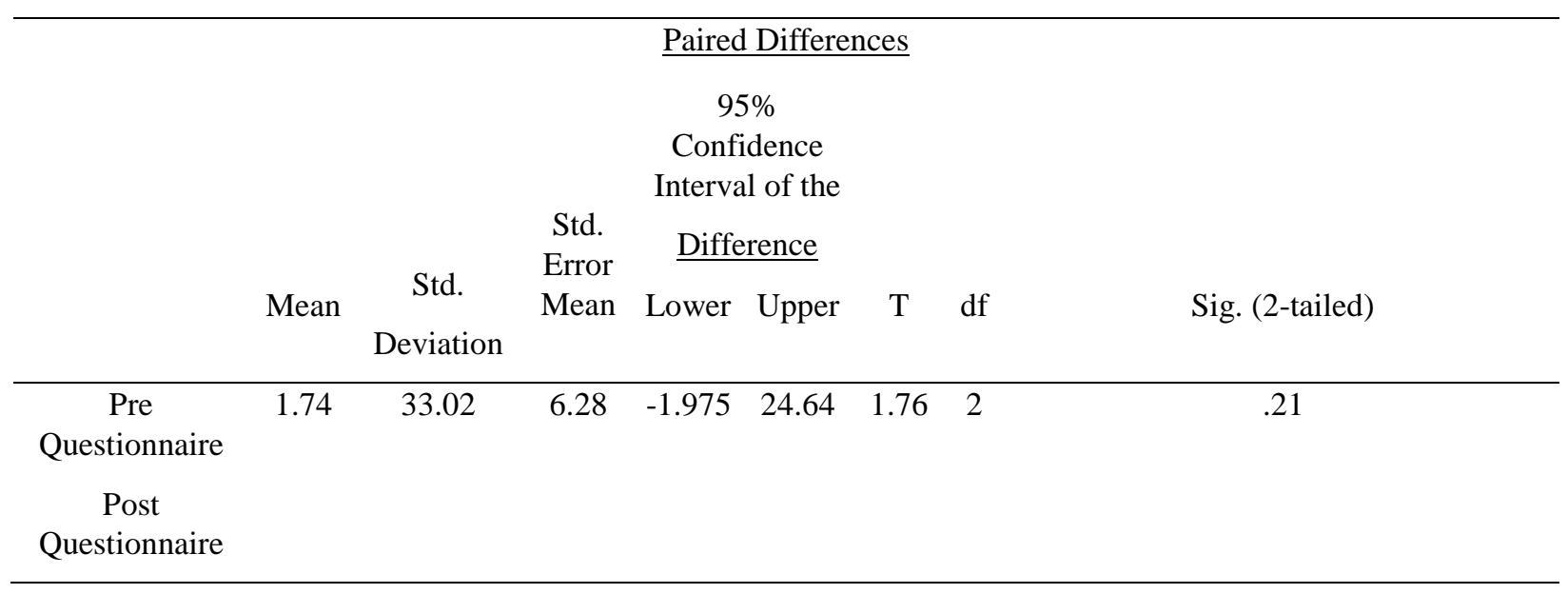


The results manifested in Table 14 revealed that the difference between the data collected before and after the treatment was not significant $(0.21>0.05)$.

\section{Discussion}

This study investigated the impact of PF on EFL learners' overall writing performance. It aimed to find out if there was a significant difference in the writing performance of the experiment group that underwent a PF process and the control group that only underwent teacher feedback process. Additionally, the students in the experiment group were investigated regarding the effect of PF on their writing anxiety.

Regarding the first research question investigating the effect of PF on EFL learners' writing performance, the results manifested that the language learners who were included within the experimental group had a statistically significant difference from those in the control group. These results are consistent with the findings obtained by other researchers (Liu, \& Carless, 2006; McLoughlin \& Luca, 2004). The findings support Kuyyogsuy's (2019) study which revealed that thanks to PF, the students' writing ability progressed. Moreover, in accordance with Brusa and Harutyunyan's (2019) and Khalil's (2018) studies, the findings support the advantageous use of PF in writing classes.

However, the results are in contrast with Rollinson's (2005) study indicating that the application of PF does not have a significant effect on the language learners' writing performance. According to Tsui and $\mathrm{Ng}$ (2000), when students comment on the writings of their peers, they benefit more than the ones who read the comments and modify the texts. By being a critical reader of their classmates' writing, students learn to examine and assess their own papers critically to identify the areas which need to be improved without being entirely dependent on their teacher's feedback (Rollinson, 2005).

Regarding the second question exploring the efficacy of PF on relieving anxiety of the language learners in writing classes, the present study came to the conclusion that the learners attended within the experimental group had less anxiety and PF can be suggested as a useful methodology for decreasing writing anxiety to a high extent. This is in line with the findings of Kurt and Atay (2007) who pointed out that peer feedback makes the learning environment less anxious and stressful because learners interact with each other, try to help their friends, find out with their mistakes, and help each other correct their mistakes in a non-judgmental environment. This results in an increase in their self-assessment and self-awareness skills. Furthermore, the findings are in line with Cinar's (2014) and Kurt and Atay's (2007) studies, indicating that writing anxiety levels decreased when compared to the levels in the beginning with the PF treatment.

According to Cheng (2002), if students are anxious in writing, they do not want to use English to write. Consequently, peer feedback creates a classroom atmosphere in which students can feel less nervous and stressed out while writing. The classroom atmosphere requires students to cooperate and collaborate with each other in giving and receiving feedback, which enables them to learn from each other (Bartels, 2003; Rollinson, 2005).

\section{Conclusion and Implications}

This study was conducted to find out whether PF had an effect on students' overall writing performance and to learn how their anxiety might be affected by PF. The findings indicated that PF enhanced students' overall writing performance and reduced their writing anxiety level. In other words, interaction among the students helped them learn from each other and reduced their anxiety and stress. This study revealed some certain implications when teaching writing. First, writing teachers can incorporate PF into their classes because PF can be effective in increasing the performance of the students and can be used by the students to revise their writings. Therefore, it would be a good idea for teachers to make PF an indispensable element of their writing classes. Moreover, the teachers should acknowledge that the students are not solely the passive recipients of knowledge and feedback provided by their teachers, and they are thoroughly capable of accomplishing the tasks that lead to their educational success. In addition, this study also supported the advantages of using peer feedback of which many researchers had considered in L2 writing classes (Yu \& Lee, 2016; Zhu \& Mitchell, 2012).

Moreover, if teachers want PF to be successful, training the students is very crucial. If the students are familiar with what they need to do and how to do it, it will result in more success. Students should know the purpose of PF, and they should think of it as one aspect of the whole writing process. Therefore, the teachers should indicate that commenting on classmates' writing is actually a learning process that helps them develop a better sense of being a 
reader who can see from the perspective of an audience. Furthermore, this experience may help them in their future professional and academic lives because they had the chance to acquire a sense of audience. Also, if teacher feedback is used along with PF, it may contribute more to the performance of the students because PF can be considered as complementary to teacher feedback. Therefore, writing teachers should be encouraged to use PF in their classrooms because writing lessons are no longer under the absolute control of teachers. Instead, writing classes are "positive, encouraging, and collaborative workshop environments within which students can work through their composing processes" (Tsui \& Ng, 2000, p.168).

Regarding the limitations of this study, the size of the sample was small. In addition, while applying this study, students were supposed to develop other skills like listening, speaking, and reading. Therefore, besides writing, students were also exposed to other types of input. Moreover, the time given to teach writing was not enough. It was not enough to enable the students to be completely familiar with PF and have enough experience to use it effectively in writing classes. In addition, the students joining the research came from an educational background in which teachers were the center of education. They were not familiar with a learning environment in which they were more required to be more active and engage in their own learning. Also, the language learners who were chosen for the present study were only female language learners.

\section{References}

Abdel Latif, M. M. (2012). Sources of L2 writing apprehension: a study of Egyptian university students. Journal of Research in Reading, 38(2), 194-212. https://doi.org/10.1111/j.1467-9817.2012.01549.x

Austria, M. A. B. (2017). Peer response as an effective writing strategy. International Journal of Progressive Education, 13(2), 95-104.

Bartels, N. (2003). Written peer response in L2 writing. English Teaching Forum, 41(1), 34-37.

Brusa, M., \& Harutyunyan, L. (2019). Peer review: A tool to enhance the quality of academic written productions. English Language Teaching, 12(5). https://doi.org/10.5539/elt.v12n5p30

Celce-Murcia, M. (1991). Teaching English as a second or foreign language. Boston, MA: Heinle \& Heinle.

Chaudron, C. (1984). The effects of feedback on students' composition revisions. RELC Journal, 15(2), 1-14. https://doi.org/10.1177/003368828401500201

Cheng, Y. (2002). Factors associated with foreign language writing anxiety. Foreign Language Annals, 35(5), 647656. https://doi.org/10.1111/j.1944-9720.2002.tb01903.x

Cheng, Y. S. (2004). A measure of second language writing anxiety: Scale development and preliminary validation. Journal of Second Language Writing, 13(4), 313-335. https://doi.org/10.1016/j.jslw.2004.07.001

Cinar, G. (2014). The effect of peer feedback on writing anxiety in English as a foreign language students (Unpublished master's thesis). Çă̆ University, Adana, Turkey.

DeDeyn, R. (2011). Student identity, writing anxiety, and writing performance: A correlational study (Unpublished doctoral dissertation). Colorado: Colorado State University.

Erkan, D. Y., \& Saban, A. I. (2011). Writing performance relative to writing apprehension, self- efficacy in writing, and attitudes towards writing: A correlational study in Turkish tertiary- level EFL. The Asian EFL Journal Quarterly, 13(1), 163-191.

Faigley, L. (1986). Competing theories of process: A critique and a proposal. College English, 48(6), 527-542. https://doi.org/10.2307/376707

Farrah, M. (2012). The impact of peer feedback on improving the writing skills among Hebron university students. An-Najah University Journal for Research, 26(1), 179-210.

Hansen, J. G., \& Liu, J. (2002). Peer response in second language writing classroom. Ann Arbor, MI: University of Michigan.

Hassan, B. A. (2001). The relationship of writing apprehension and self-esteem to the writing quality and quantity of EFL university students. Mansoura Faculty of Education Journal, 39, 1-36. 
Hendrickson, J. (1978). Error correction in foreign language teaching: Recent theory, research, and practice. Modern Language Journal, 62(8), 387-398. https://doi.org/10.2307/326176

Huang, M. C. (2004). The use of process writing and Internet technology in a Taiwanese college English writing class: A focus on peer reviews. (Doctoral dissertation). The Pennsylvania State University.

Huang, Q. (2012). Study on correlation of foreign language anxiety and English reading anxiety. Theory \& Practice in Language Studies, 2(7), 55-67.

Hussein, S. (2013). An investigation into the factors that associated with writing anxiety for English language learners in UAE universities. (Unpublished doctoral dissertation). Dubai: The British University.

Hyland, K. (2003). Second language writing. Cambridge: Cambridge University.

Jahin, J. H. (2012). The effect of peer reviewing on writing apprehension and essay writing ability of prospective EFL teachers. Australian Journal of Teacher Education, 37(11), 60- 84. doi: 10.14221/ajte.2012v37n11.3

Keh, C. L. (1990). Feedback in the writing process: a model and methods for implementation. ELT Journal, 44(4), 294-304. https://doi.org/10.1093/elt/44.4.294

Khalil, E. (2018). The efficacy of peer feedback in Turkish EFL students' writing performance. Journal of Literature and Art Studies, 8(6), 920-931. doi: 10.17265/2159-5836/2018.06.011

Koka, A., \& Hein, V. (2006). Perceptions of teachers' general and informational feedback and intrinsic motivation in physical education: Two-year effects. Perceptual and Motor Skills, 103, 321-332. https://doi.org/10.2466/pms.103.2.321-332

Kurt, G., \& Atay, D. (2007). The effects of peer feedback on the writing anxiety of prospective Turkish teachers of EFL. Journal of Theory and Practice in Education, 3(1), 12-23.

Kuyyogsuy, S. (2019). Promoting peer feedback in developing students' English writing ability in L2 writing class. International Education Studies, 12(9), 76-90. doi:10.5539/ies.v12n9p76

Lei, Z. (2017). Salience of student written feedback by peer-revision in EFL writing class. English Language Teaching, 10(12), 151-157. doi:10.5539/elt.v10n12p151

Leki, I. (1991). The preferences of ESL students for error correction in college-level writing classes. Foreign Language Annals, 24(3), 203-218. https://doi.org/10.1111/j.1944-9720.1991.tb00464.x

Lindeman, E. (1982). A rhetoric for writing teachers. New York: Oxford University Press.

Liu, J., \& Hansen, J. G. (2002). Peer response in second language writing classrooms. Ann Arbor, MI: The University of Michigan Press.

Liu, M., \& Ni, H. (2015). Chinese university EFL learners' foreign language writing anxiety: Pattern, effect and causes. English Language Teaching, 8(3), 46-58. doi:10.5539/elt.v8n3p46

Liu, N. F., \& Carless, D. (2006). Peer feedback: the learning element of peer assessment. Teaching in Higher Education, 11(3), 279-290. doi: 10.1080/13562510600680582

Malec J. F. (2011). Mayo-Portland adaptability inventory. In: Kreutzer J.S., DeLuca J., Caplan B. (eds) Encyclopedia of clinical neuropsychology. Springer, New York, NY. https://doi.org/10.1007/978-0-387-79948-3_1818

Mangelsdorf, K., \& Schlumberger, A. (1992). ESL student response stances in peer review task. Journal of Second Language Writing, 1(3), 235-254. https://doi.org/10.1016/1060-3743(92)90005-A

McLoughlin, C., \& Luca, J. (2004). An investigation of the motivational aspects of peer and self- assessment tasks to enhance teamwork outcomes. Edith Cowan University Research Online ECU Publications Pre. 2011, 629-636.

Mendonca, C. O., \& Johnson, K. E. (1994). Peer review negotiations: Revision activities in ESL writing instruction. TESOL Quarterly, 28(4), 745-769. https://doi.org/10.2307/3587558

Min, H. T. (2005). Training students to become successful peer reviewers. System, 33(2), 293-308. https://doi.org/10.1016/j.system.2004.11.003 
Min, H. T. (2016). Effect of teacher modeling and feedback on EFL students' peer review skills in peer review training. Journal of Second Language Writing, 31, 43-57 .https://doi.org/10.1016/j.jslw.2016.01.004

Nelson, G. L., \& Murphy, J. M. (1993). Peer response groups: Do L2 writers use peer comments in revising their Drafts? TESOL Quarterly, 27(1), 135-141. https://doi.org/10.2307/3586965

Nicol, D. (2010). From monologue to dialogue: improving written feedback processes in mass higher education. Assessment \& Evaluation in Higher Education, 35(5), 501-517. https://doi.org/10.1080/02602931003786559

Onozawa, C. (2010). A study of the process writing approach. RESEARCH NOTE, 10, 153-163.

Rahimi, M. (2009). The role of teacher's corrective feedback in improving Iranian EFL learners' writing accuracy over time: Is learner's mother tongue relevant? Reading and Writing, 22(2), 219-243.

Richards, J. C., \& Lockhart, C. (1994). Reflective teaching in second language classrooms. Cambridge: Cambridge University Press.

Richards, J. C., \& Rodgers, T. S. (1986). Approaches and methods in language teaching. Cambridge University Press.

Rollinson, P. (2005). Using peer feedback in the ESL writing class. ELT Journal, 59(1), 23-30. https://doi.org/10.1093/elt/cci003

Soleimani, M., \& Modirkhamene, S. (2020). Various corrective feedback types in collaborative vs. individual writing conditions. IJREE, 24-39. http://ijreeonline.com/article-1-352-en.html

Susoy, Z., \& Tanyer, S. (2013). A closer look at the foreign language writing anxiety of Turkish EFL pre-service teachers. Paper presented at the International Academic Conference on Education, Teaching, and E-learning. Prague, Czech Republic.

Tsui, A. B. M., \& Ng, M. (2000). Do secondary L2 writers benefit from peer comments? Journal of Second Language Writing, 9(2), 147-170. https://doi.org/10.1016/S1060-3743(00)00022-9

Widdowson, H. G. (1984). Reading and communication. In C. Alderson \& A. Urquhart (Eds.), Reading in a foreign language (pp. 213-227). New York: Longman.

Xiu Yan, J., \& Wang, H. (2012). Second language writing anxiety and translation: Performance in a Hong Kong tertiary translation class. The Interpreter and Translator Trainer, 6(2), 171- 194. https://doi.org/10.1080/13556509.2012.10798835

Yastibas, G. C., \& Yastibas, A. E. (2015). The effect of peer feedback on writing anxiety in Turkish EFL (English as a foreign language) students. Social and Behavioral Sciences, 199, 530-538. doi: 10.1016/j.sbspro.2015.07.543

Yu, S., \& Lee, I. (2016). Peer feedback in second language writing (2005-2014). Language Teaching, 49(4), 461-493.

Zhu, W., \& Mitchell, D. A. (2012). Participation in peer response as activity: An examination of peer response stances from an activity theory perspective. TESOL Quarterly, 46(2), 362-386. https://doi.org/10.1002/tesq.22 